\title{
Null Subjects in Contemporary Brazilian Filmic Speech
}

Gian Luigi De Rosa ${ }^{a}$

\begin{abstract}
The present research, based on a corpus of contemporary Brazilian filmic speech - Urban Carioca Sub-Corpus from the I-Fala Corpus of Luso-Brazilian Film Dialogues as a resource for L1 \& L2 Learning and Linguistic Research (DE ROSA et al., 2017) -, illustrates how Brazilian Portuguese (BP) has undergone a process of change regarding the representation of referential subjects. A preference for overt pronominal subjects is on the rise, thus transitioning contemporary Brazilian Portuguese from a null subject language to a partial null subject language. The current paper revisits De Rosa (2017), this time including third person subjects and using actual film dialogue transcriptions rather than scripts. The occurrence of null and overt subjects in the corpus is discussed both quantitatively and qualitatively.
\end{abstract}

Keywords: Brazilian Portuguese; null subject languages; (overt and null) referential pronominal subject; filmic speech; European Portuguese. 


\section{Introduction}

The neostandard variety ${ }^{1}$ of Brazilian Portuguese (henceforth $\mathrm{BP}$ ) has been undergoing a series of linguistic changes resulting in a gradual loss of the characteristics of a null-subject language (such as Italian or European Portuguese (henceforth EP)), thereby moving from a pro-drop to a partial pro-drop language. This has been attested by many studies which have analyzed data from spoken language (LIRA, 1988, 1996; DUARTE, 1995, 1998, 2000; BERLINCK; DUARTE; OLIVEIRA, 2015), written language (PAREDES SILVA, 1988,

${ }^{1}$ By neostandard BP, we mean the variety of BP in common use, employed by educated, urban Brazilian speakers, and which can be considered a new standard under development, whose constructions, forms and more salient achievements are also registered in the most monitored text genres. It is a variety that is sensitive to diatopic differentiation, and thereforefundamentally corresponds - in its concrete use by speakers - to urban cultured varieties (we do not use the phrase 'urban cult speech' because the use of neostandard $\mathrm{BP}$ is also, as previously mentioned, present in written text genres).

${ }^{2}$ As well as sentences with the null expletive, neostandard B P has cases where the argument reaches the subject position, such as in: sentences with meteorological verbs (e.g. "São Paulo chove muito no inverno", "Essas florestas chovem muito"); impersonal constructions with a subject (e.g. "Ele parece que vem amanhã", "Eu pareço que vou explodir de raiva"); and existential constructions with a subject (e.g. "Essa cidade tem muita praia”, “O Rio tem prédios lindos"), see Kato and Duarte (2014, p. 156). 1991, 2003), theatrical speech (DUARTE, 1993, 2012) and filmic speech (DE ROSA, 2017). The increasing use of pronominal subjects over time in BP (KAISER, 2006, p. 11), is accompanied by weakening verbal morphology with a consequent reduction of the verbal paradigm (verb inflections for number and person have been reduced to $3 / 4$ forms) and by a restructuring of the pronominal system.

According to the aforementioned studies, neostandard BP allows more frequent mention of referential subjects and more frequent filling of the subject position than standard varieties of $\mathrm{EP}$ and $\mathrm{BP}$, in relation to:

a) Arbitrary pronominal subjects:

"Eles deveriam ensinar amor às crianças"

(CYRINO; DUARTE; KATO, 2000, p. 62);

b) Pronominal subjects with [-animate] co-referent:

"A casa virou um filme quando ela teve de ir abaixo" (DUARTE, 2000, p. 22);

c) Left dislocated subjects (double subject)

"O Paulo ele gosta de cinema brasileiro".

Nevertheless, aside from contexts of resistance where it is possible to omit the referential subject in the third person singular, the omission of non-referential subjects can still be observed in sentences with meteorological verbs ("ø chove"), in impersonal constructions ("ø parece que ele vem amanhã") and in existential structures with "ter" and "haver" ("ø Tem muita praia nessa cidade"), where there are expletive null subjects. ${ }^{2}$ There are also cases of null subjects of arbitrary reference, 
3 These constructions are only fully acceptable when the subject is being focused upon, i.e. when it concerns new information or when there is a contrast (LOBO, 2013, p. 2310-1).

${ }^{4}$ In De Rosa (2017), data on referential subject position filling in movie script dialogues were an alysed, whereas the present study uses transcripts from the découpage made after the films were assembled, and which are part of the I-FALA Corpus of LusoBrazilian Film Dialogues as a resource for $L 1 \mathcal{E}$ L2 Learning and Linguistic Research (DE ROSA et al., 2017). The movie scripts appeared to be more conservative, in that the percentage of subject position filling was lower than that registered here; this is why it was important to revise De Rosa's (2017) conclusions.

${ }^{5}$ The only exception is Central do Brasil, which is more of a road movie. such as: "Hoje em dia não ø usa mais máquina de escrever"; "ø Bateram à porta".

Moreover, in some cases it is still possible, as happens in pro-drop languages, to invert the constituents of the sentence, putting the subject either at the end of the sentence (VOS) ("comeram o bolo as crianças") or in a post-verb position in passive constructions ("Foi convidado só ele") ${ }^{3}$ and with unacusative verbs ("Chegou o rapaz").

Against this background, the present study, which revisits De Rosa (2017) ${ }^{4}$ and adds data on third person overt and null subject pronouns, aims to analyze this linguistic change in contemporary Brazilian filmic speech in a sample of ten films produced between 1996 and 2013, showing a reflection of, and a phenomenon triggered by, the restandardization of BP. The transcripts of spoken dialogue from the films, which were set almost exclusively in the city of Rio de Janeiro, ${ }^{5}$ are included in the Urban Carioca Sub-Corpus from the I-Fala Corpus of Luso-Brazilian Film Dialogues as a resource for L1 \& L2 Learning and Linguistic Research (DE ROSA et al., 2017)

The analysis only considered referential (overt or null) subject pronouns in finite sentences, given that, according to the referential hierarchy proposed by Cyrino, Duarte and Kato (2000, p. 54) (Fig. 1), referentiality has translinguistic relevance in pronominalization.

Fig. 1. Referential hierarchy.

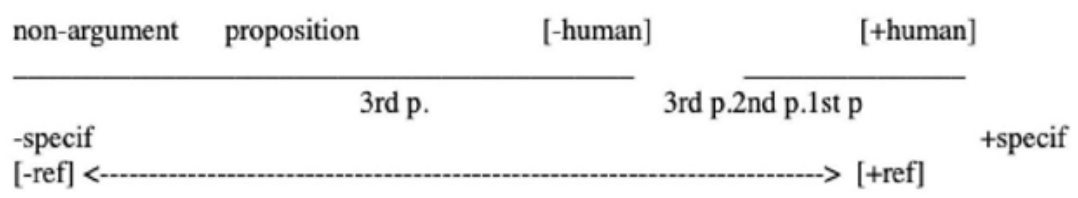

Source: (Cyrino; Duarte; Kato, 2000, p. 54).

According to their hypothesis, argument pronouns with the traits [ $+\mathrm{N},+$ human] are found at the highest end of the referential hierarchy, while non-argument pronouns are found at the opposite end.

In computing the data, we excluded sentences with verbs in the imperative and coordinates with co-referential subjects, as well as all cases in which the subject pronoun cannot be omitted because it is accompanied by a focusing 
element ("só você", "até a gente"), an emphasizing element ("ele mesmo"), numerals ("nós quatro") and verb forms equivalent to affirmative and emphatic answers.

\section{The evolution of pronominal subjects in neostandard BP}

In her studies on subject in BP - indispensable for all of those wishing to analyze this phenomenon -, Maria Eugenia Lamoglia Duarte (1993, 1995, 1998, 2000, 2004, 2008, 2012) witnessed an evolution in the use of pronominal subjects in BP starting from the second half of the $19^{\text {th }}$ century. The author analyzed this phenomenon in both spontaneous speech and the theatrical speech of popular Brazilian plays, observing an increasing trend in the use of subject pronouns in finite sentences (those that exhibit the verb inflected for time, mode, number and person), whereas EP permits null subjects in finite sentences since it has a rich system of verb agreement (inflectional richness).

The results, reproduced in the following graph, indicate a gradual transition taking neostandard $\mathrm{BP}$ from a null subject language to a partial null subject language. The graph shows Duarte's (2000, p. 19) results from readapting null subject data in her theatrical corpus (1993, p. 112), diverting attention from the percentage of overt subjects.

\section{Graph 1.}

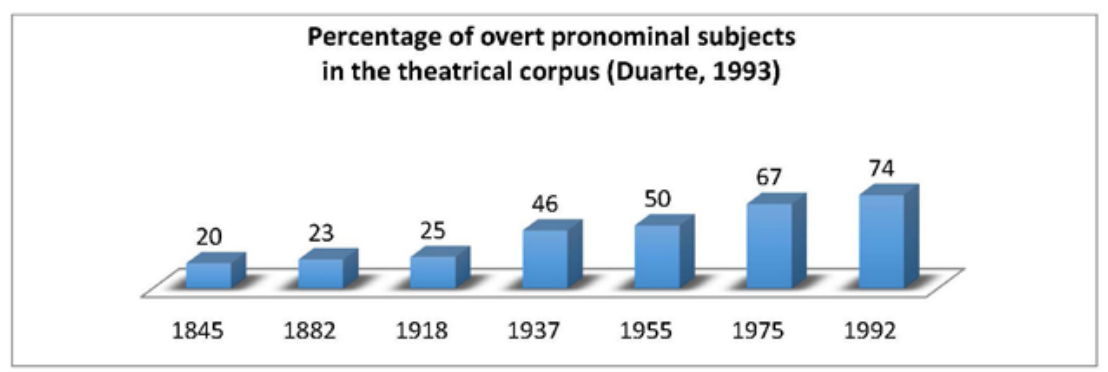

Source: Data from Duarte (2000, p. 19)

This change can be placed within neostandardization process of $\mathrm{BP}$ in which acceptance of marked constructions specific to non-standard oral varieties (monitored and not) in the new standard currently being formed is becoming 
6 "[El] morfema de persona incluido en el verbo distingue ya cuál de las tres funciona como sujeto gramatical, y así no resulta muy necesaria la presencia de un sustantivo personal para señalar un sujeto explícito: en canto, cantas, canta, están ya expresas como sujeto las personas primera, segunda y tercera, respectivamente. No obstante, es frecuente la aparición de un personal en esa función de sujeto explícito, y no solo en los caso de coincidencia fónica de las formas verbales (como cantaba, cantaría, cante, en que no se distingue la primera de la tercera persona), ni en el caso de la tercera persona (donde la distinción de géneros del personal puede aportar mayor precisión acerca de la referencia concreta al sujeto). También pueden aparecer yo y tú, aunque su referencia personal es evidente e inequívoca en cada acto de habla. Por tanto, la aparición de los sustantivos personales en estos casos de redundancia, tiene marcado carácter enfático y expresivo, y trata de contraponer la persona aludida a las otras" (ALARCOS LLORACH, 1999, p. 73). increasingly diffuse. In this process, the order of elements in a sentence has a certain relevance. In fact, in this regard, it is necessary to restate that, while in standard BP, the "unmarked" order of constituents in a sentence is still considered (S)VO (Subject-Verb-Object) and the subject can be omitted because standard BP has a rich inflectional paradigm, in neostandard BP the "unmarked" order of constituents is SV(O), effectively due to the linguistic changes we are talking about: greater subject pronoun expression and omission of the object clitic, especially the third person accusative (TARALLO, 1993, p. 70).

Thus, the parametric change involves and affects neostandard BP (or urban cultured varieties) and not standard BP. These two definitions (neostandard and urban cultured varieties) can be considered relatively interchangeable - the definition of neostandard mainly refers to the unitary traits of the diassystem, relative to the morphosyntactic level, which constitute the usual variety of language used by urban cult speakers. The definition of urban cultured varieties refers to the differentiating aspects associated with diatopic variation, mainly perceptible on the phonetic-prosodic and lexical levels.

The pro-drop parameter makes a distinction between languages in which a pronominal subject is obligatory (they have weak verbal morphology) and languages in which the pronominal subject is optional (where the subject can be inferred from verbal morphology). Kato (2000, p. 207), in line with Chomsky (1981) and Rizzi (1982), states that "The null subject (NS) parameter has been proposed to be a cluster of properties, including: [a] the possibility of null subjects; [b] free inversion/postponed subjects". In practice, a language can be defined as pro-drop if it allows omission of the subject, free inversion with the postponed subject, and has limited use of the pronominal subject in restricted contexts, as attested by the grammar of the Real Academia Española for standard Spanish, a pro-drop language. ${ }^{6}$ This is also true for standard and neostandard Italian, a pro-drop language in which, for example, the subject of a meteorological verb can be performed by an implicit pronoun (without phonetic realization), e.g. “므 nevica". By contrast, in English, a non pro-drop language, the subject position must be occupied by an expletive (or pleonastic) pronoun with phonetic realization, which is devoid of meaning or reference, e.g. "it is snowing". 
As for BP, Duarte (1993, p. 109-110) stresses that the simplification of pronominal and verbal paradigms has played a fundamental role in its evolution from pro-drop to partial pro-drop language.

This is even clearer in the following visuals, in which the verbal paradigm of standard $\mathrm{BP}$ is confronted with that of the neostandard $\mathrm{BP}$, a language variety that accepts the concomitance of "nós" and "a gente" as first person plural. The two pronouns present themselves as co-occurring, competing forms, although there is a difference in use associated with the diamesic and diaphasic axes of variation. The pronoun "nós" still resists in formal and monitored registers of written $\mathrm{BP}$, while "a gente"has become the most commonly used pronominal form among young people; yet it is also conquering other age groups, replacing the first person plural form "nós" in almost all oral and informal contexts.

Table 1 shows the paradigm of standard BP and neostandard BP, and Figure 2 illustrates the architecture model of BP:

Table 1.

\begin{tabular}{|c|c|c|c|}
\hline PERSON & NUMBER & STANDARD BP & NEOSTANDARD BP \\
\hline $1^{\text {ST }}$ & SINGULAR & CANT-O & CANT-O \\
\hline $2^{\text {ND }}$ DIRECT & SINGULAR & CANTA-S & ------ \\
\hline $2^{\text {ND }}$ INDIRECT & SINGULAR & CANTA- $\emptyset$ & CANTA- $\varnothing$ \\
\hline $3^{\text {RD }}$ & SINGULAR & CANTA- $\varnothing$ & CANTA- $\varnothing$ \\
\hline $1^{\text {ST }}$ & PLURAL & CANTA-MOS & CANTA-MOS/CANTA- $\varnothing$ \\
\hline $2^{\text {ND }}$ DIRECT & PLURAL & CANTA-IS & ----- \\
\hline $2^{\text {ND }}$ INDIRECT & PLURAL & CANTA-M & CANTA-M \\
\hline $3^{\text {RD }}$ & PLURAL & CANTA-M & CANTA-M \\
\hline
\end{tabular}

Fig. 2. Architecture model of BP.

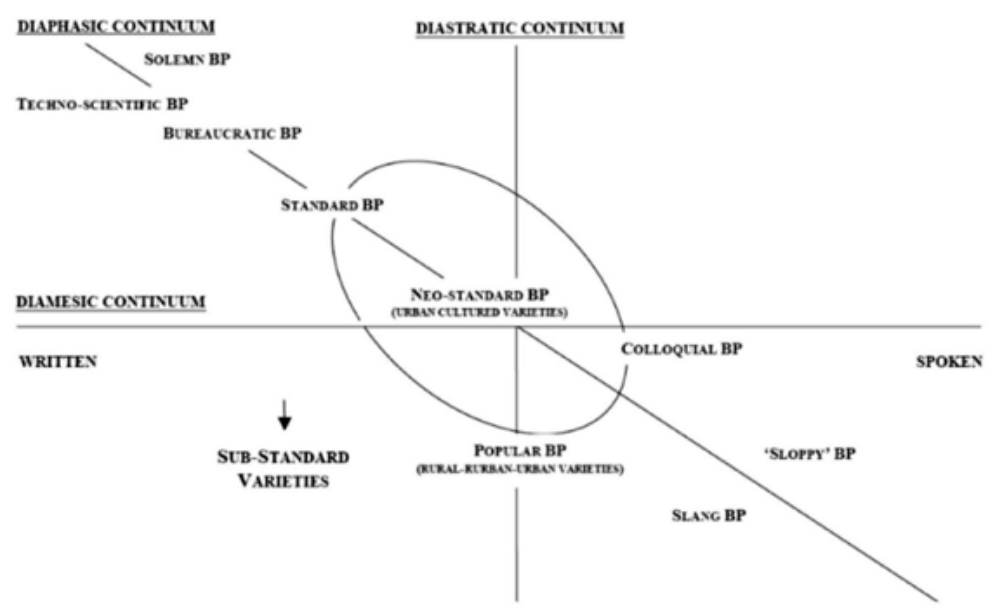

Source: De Rosa, 2012 
This type of change falls under the first of the four cases of differentiation and distance between EP and BP identified by Tarallo (1993, p. 70) in his pioneering study on the emergence of a Brazilian grammar in the $19^{\text {th }}$ century. His research discussed a reorganization of the pronominal system in $\mathrm{BP}$, with the most significant outcomes being more frequent lexical subjects as well as the occurrence of null objects.

This state of affairs makes neostandard BP a (variety of) language with a reduced verbal inflectional system, the main consequence of which is a higher frequency of expressed pronominal subjects, due to the direct relationship between the richness of the verbal paradigms of a language and the possibility of omitting the subject in finite sentences (DUARTE, 1993, p. 107).

\section{Overt subjects in contemporary Brazilian filmic speech}

The 6494 pieces of data collected for this study examined the referential pronominal subjects (whether overt or null) of finite time sentences taken from a sample of ten Brazilian films in the Urban Carioca Sub-Corpus, I-Fala Corpus (DE ROSA et al., 2017). Table 2 lists the ten films, their year of production and the quantity of relevant data collected from each of these films.

Table 2.

\begin{tabular}{|l|l|l|}
\hline Year & Film & Data \\
\hline 1996 & Pequeno Dicionário Amoroso & 592 \\
\hline 1998 & Central do Brasil & 619 \\
\hline 2004 & O Redentor & 507 \\
\hline 2006 & Se eu fosse você & 877 \\
\hline 2006 & Muito gelo e dois dedos d'água & 639 \\
\hline 2006 & Trair e coçar é só começar & 816 \\
\hline 2007 & Meu nome não é Johnny & 768 \\
\hline 2007 & Cidade dos Homens & 619 \\
\hline 2008 & Verônica & 463 \\
\hline 2013 & Alemão & 593 \\
\hline
\end{tabular}

The variable, i.e. the occurrence of overt or null pronominal subjects, was crossed with the following morphosyntactic factors: 
a) Syntactic trait of number and person in relation to the designated semantic trait (person of the discourse);

b) time and verb form (simple or compound);

c) type of sentence;

d) presence of elements before the subject or between the subject and verb;

and with extralinguistic factors related to the year of production and the film genre.

\subsection{Results}

\subsubsection{Grammatical number and person}

In the filmic speech in our corpus, there is a predominance of overt subjects over null subjects. However, while we recorded a subject pronoun fill rate of $71 \%$ for the first person and $71.68 \%$ for second person subject pronouns, the results are still conservative compared to Duarte's (1993) data on theatrical speech, which, for the 1990s, recorded an expressed subject rate of $82 \%$ for first person pronouns and $78 \%$ for second person pronouns. It is also less predominant than in the existing data on spontaneous speech (DUARTE, 2004; BARBOSA; DUARTE; KATO, 2005), which recorded a subject pronoun fill rate of $74 \%$ for the first person and $90 \%$ for second person pronouns. Regarding the rate of overt third person pronouns, we noted a slight inversion of the tendency, given that it was found to be $45 \%$ in theatrical speech (DUARTE, 1993) and 58\% in spontaneous speech (DUARTE, 1995, 2004; BARBOSA; DUARTE; KATO, 2005), compared to an average of $60.89 \%$ in filmic speech (503 out of 826 of the data entries; $63.09 \%$ for third person singular and $47.42 \%$ for third person plural). However, this last observation regarding third person pronouns in filmic speech is still far from the data presented in Berlinck et al. (2015), in which an average of $75.80 \%$ of third

${ }^{7}$ As for first person $(81 \%)$ and second person $(86 \%)$ pronouns, the data illustrated in Berlinck et al. (2015) closely approximate the figures on theatrical speech (DUARTE, 1993) person subject pronouns were expressed $(78 \%$ for third person singular and $71 \%$ for third person plural). ${ }^{7}$

An analysis of our Urban Carioca Sub-Corpus highlights a consistent subject expression rate starting from Pequeno Dicionário Amoroso (69.25\%) produced in 1997, and Central do Brasil (68.65\%) produced in 1998. Along with Trair e coçar é 
só começar (69\%) of 2006, Meu nome não é Johnny (63.80\%) and Cidade dos Homens (66.88\%), both from 2007, these are among the most conservative figures. This is a comedy and four drama films in which the frequency of overt subjects remained below $70 \%$. In the first film, the narration made by the protagonists themselves keeps the filmic speech well monitored, but, despite this, the null subject is not found in greater frequency. In the second film, the main character, Dora, is a former teacher, so her speech greatly increases the percentage of null subjects, mainly for the third person singular and the standard first person plural. Even in the comedy Trair e coçar é só começar, centered on the misunderstandings of an employee in the daily routine of a family of Rio's upper bourgeoisie, null subject use does not go beyond 69\%. However, Meu nome não é Johnny and Cidade dos Homens are singular cases. They have a subject position fill rate of just $63.80 \%$ and $66.88 \%$ respectively, revealing rather strong control in their rendering of spontaneous speech. This is in fact not very credible, considering that both films deal with drug trafficking in the South Zone of Rio de Janeiro.

Graph 2 shows the percentages of overt and null pronominal subjects in our film corpus.

Graph 2. Percentage of overt and null subjects in the Urban Carioca Sub-Corpus.

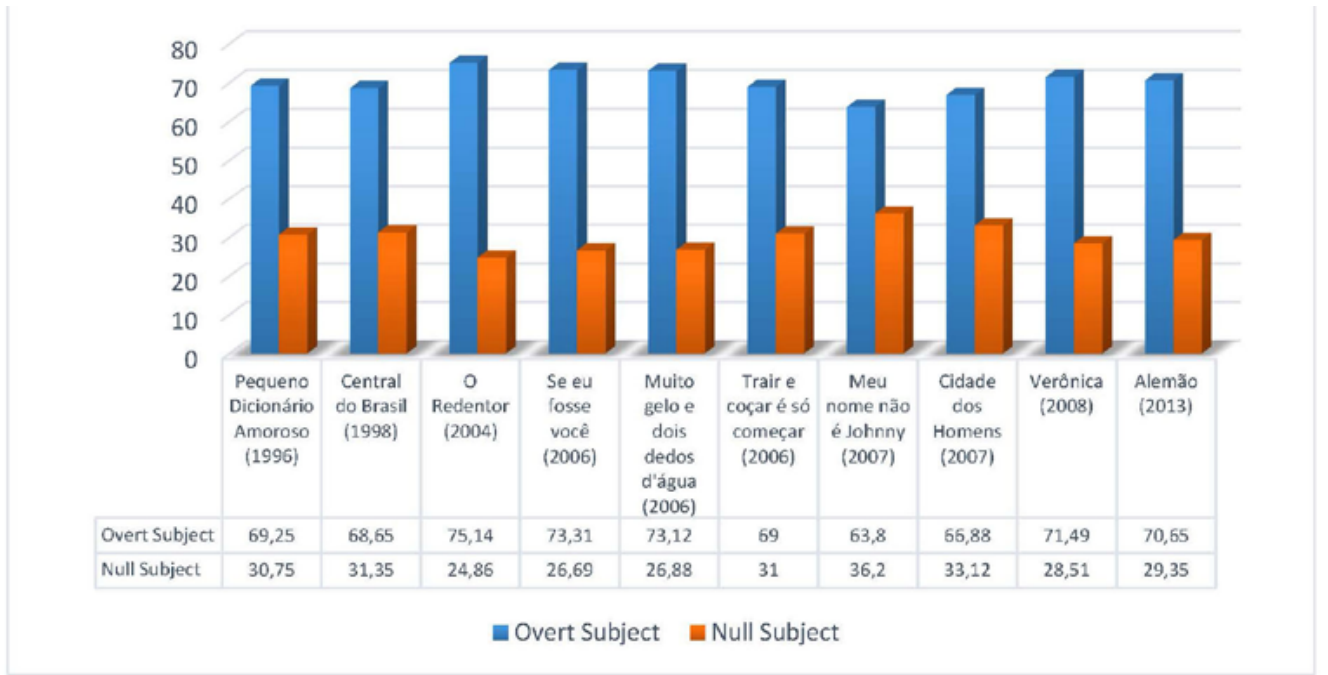

Source: I-FALA 
As previously mentioned, we can detect a consistent tendency to overtly express the subject, with the subject position being filled at least $63.8 \%$ of the time (Meu nome não é Johnny).

Table 3 shows the occurrences of each of the pronominal forms (first person, second person and third person in the singular and plural) in order to gain a precise idea about the process of change observed in the film corpus.

Table 3.

\begin{tabular}{|l|l|l|}
\hline Pronominal Form & Overt Pronoun/Total & $\%$ \\
\hline EU & $2163 / 3118$ & $69,37 \%$ \\
\hline TU/VOCÊ & $1382 / 1943$ & $71,12 \%$ \\
\hline ELE/ELA & $452 / 710$ & $63,09 \%$ \\
\hline A GENTE & $300 / 311$ & $96,46 \%$ \\
\hline NOS & $102 / 180$ & $56,66 \%$ \\
\hline VOCÊS & $94 / 116$ & $81 \%$ \\
\hline ELES/ELAS & $55 / 117$ & $47,42 \%$ \\
\hline
\end{tabular}

Here, "tu" and "você" have been presented together, because, although the use of "tu" (with the verb in the zero form) reflects the diastratia and diaphasia of Rio de Janeiro's sociolinguistic situation, in the films where there were frequent occurrences, there was a mixed treatment and continual alternation of " $\mathrm{tu}$ "|"você".

To understand the situation more deeply, our objective was to examine the representation of overt pronominal subjects according to the person(s) being referred to, especially for the small number of data entries relating to the plural. However, some particularities of usage, such as the fact that the cooccurrence and competition between "nós" and "a gente" still make it possible to use the standard first person plural as a strategy to omit the subject, made us inclined to analyze only the pronouns concerning the person of the discourse, but distinguished by number.

Graph 3 shows the percentages of overt pronominal subject occurrences of the first person singular ("eu") and first person plural ("nós"/ "a gente") within our sample: 
Graph 3. Percentage of overt pronominal subject occurrences - data for 1PS and 1PP.

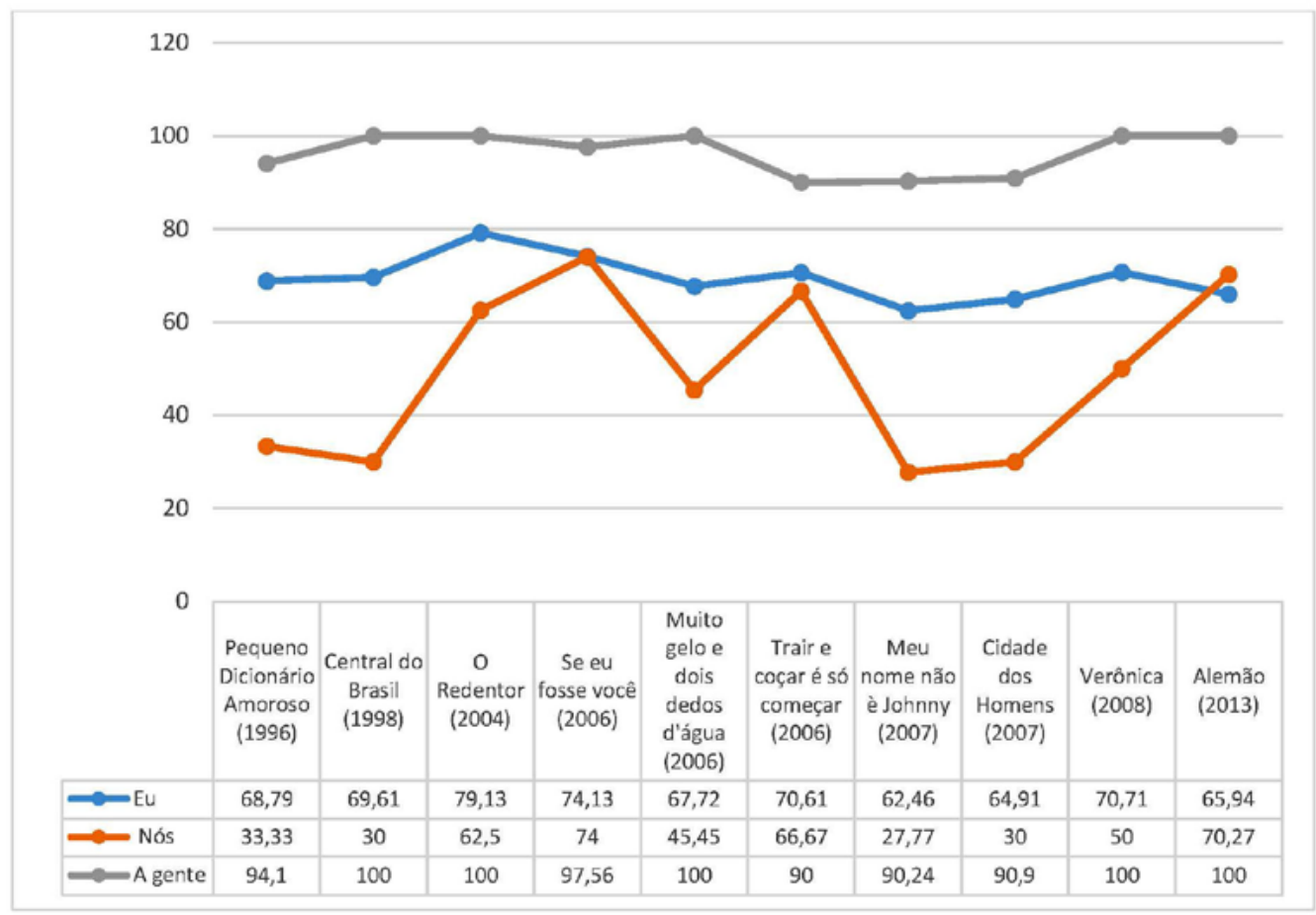

With regard to the first person plural, the data show that, in filmic speech, the use of the pronominal form "a gente" is expanding. In fact, "a gente" as an overt referential subject reached a fill rate of $96.46 \%$ (300 out of 311 ocurrences). Meanwhile, the omission of the subject for the standard first person plural "nós", although remaining high due to the morphological desinence "-mos", does not move beyond $43.34 \%$ (78 out of 180 occurrences).

(1) De qualquer forma, nós demos o primeiro passo. $\varnothing$ Entramos dentro do Complexo do Alemão.

(Alemão)

(2) ...como se ø fôssemos uma família.

(Central do Brasil) 
(3) Já reparou que ø nos encontramos só em função dos eventos dos nossos maridos?

(Se eu fosse você)

In a nutshell, the data simply confirm the advanced state of the process of pronominalisation of "a gente", which has already replaced "nós" in almost all contexts.

(4) - Então quem cuida de vocês?

- A gente mesmo cuida da gente.

(Central do Brasil)

(5) - Qual é, Tina, vai lá no barraco, pega os rádioø e umas pistola, tá ligado? Qual é, Bete! Vai lá, olha nos cana e fala que a gente vai passar.

- Demorou.

(Cidade dos Homens)

(6) - Quando você e meu pai seguraram essa agência aqui o mundoera outro, atecnologiaera outra, aeconomiaeraoutra. - A gente vai levando! Uma conta aqui, outra ali, e as coisas melhoram.

(Se eu fosse você)

Regarding the first person singular, the subject pronoun is very regularly expressed, with peaks around $70 \%$ of the oral discourse in three films: Verônica (70.71\%), Pequeno Dicionário Amoroso (70.61\%), Muito gelo e dois dedos d'água (70.84\%), and exceeding $74 \%$ in two films: Se eu fosse você (74.13\%) and $O$ Redentor (79.13\%).

(7) É como se eu não existisse. É como se eu não tivesse vontade própria. Como se eu só servisse pra ficar equilibrando as tensões... entre o Cláudio e a Bia, entre minha mãe e o Cláudio, entre o coral e a minha casa... A sensação que $e u$ tenho é que se $e u$ não estiver ali sempre... (Se eu fosse você) 
(8) Mas eu não sei de nada. Quando cheguei na favela... a polícia já tava lá. Eu cheguei com esse menino, ø já tavam lá. Eles sabem muito mais do que eu! (Verônica)

(9) Otávio, o problema é que eu estive pensando... e eu acho que Deus quer que $e u$ te denuncie.

(O Redentor)

Concerning second person pronouns, as previously mentioned, "tu" and "você" were presented as a single row in Table 3. However, it should be remarked that we found 251 occurrences of the pronoun " $\mathrm{tu}$ " as an indirect allocutive pronoun - second person singular zero form $(\varnothing),{ }^{8}$ i.e. with the same verb forms of the third person singular - in 8 of the 10 films in our corpus: Alemão (55 occurrences), Cidade dos Homens (110 occurrences), Meu nome não é Johnny (65 occurrences), Se eu fosse você (2 occurrences), Verônica (2 occurrences), Trair e coçar é só começar (5 occurrences), Central do Brasil (11 occurrences) and Muito gelo e dois dedos d'água (1 occurrence).

(10) Quero que tu seja papo reto com a rapaziada. $\mathrm{Tu}$ fecha com nós nessa porra?

${ }^{8}$ In our Urban Carioca Sub-Corpus there were also 6 occurrences of the pronoun " $\mathrm{tu}$ " as a direct allocutive pronoun (second person singular of standard $\mathrm{BP})$, triggered by its specific number-person $2 \mathrm{P}$ ending. However, we noted its use was exclusively limited to religious discourse and therefore decided not to include these occurrences.

(11) - Tu guardou? Pô, maneiro.

- Ó, mas não vai levar essa porra pro colégio, hein, moleque?

(Meu Nome Não é Johnny)

Graph 4 presents a chart with the percentages of overt subject occurrences of second person singular ("tu"/"você") and second person plural ("vocês") within our sample: 
Graph 4. Percentage of overt pronominal subject occurrences - data for 2PS and 2PP.

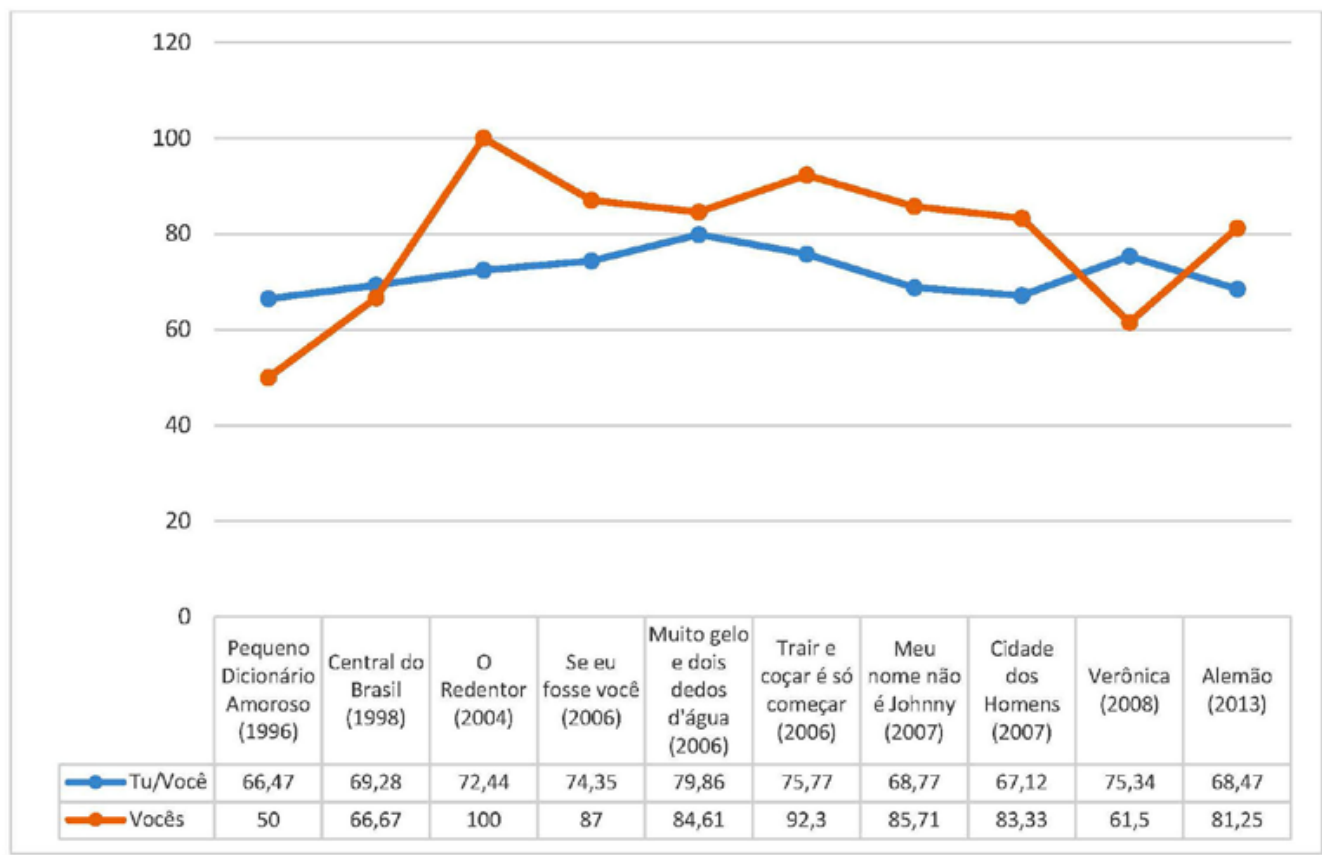

As noted earlier, the data show a regular progresssion in the second person singular form being expressed, oscillating between $66.47 \%$ in Pequeno Dicionário Amoroso and $79.86 \%$ in Muito gelo e dois dedos d'água. On the other hand, the expression of the second person plural form shows a discrepancy between 50\% (Pequeno Dicionário Amoroso) and 100\% (O Redentor), though it must be said that the data are very limited. These figures are lower than Duarte (1995)'s findings on spontaneous speech, which register $90 \%$ overt subject occurrences for the second person - thus revealing a slightly conservative trait present in filmic speech.

Below are some film dialogue excerpts with the second person singular expressed. These examples also demonstrate the mixed usage of the pronouns "tu" and "você":

(12) Mas se você conseguir, quanto é que vai custar? 50 pau? Tu tá metendo a faca, Shiro. Tá bom, fazer o quê? Manda. Tá bom, manda!

(Trair e coçar é só começar) 
(13) - Você já morreu, sua filha da puta!

- Piranha! Vagabunda! Tu tá morta, desgraçada! Tu tá morta! Sua filha da puta! Desgraçada!

(Central do Brasil)

(14) A casa caiu pra você, rapaz. A casa caiu pra você. O Juiz viajou, tá? Volta só na segunda-feira. Tu vai amargar uma cadeia, no mínimo, até terça-feira. (Muito gelo e dois dedos d'água)

(15) - Eu manjo a tua praia, viu, garoto? A Bia ainda não tem 15 anos, então você pensa direitinho onde tu quer enfiar esse teu pauzinho, porque senão um dia tu perde ele! Sacou?

- Saquei! Saquei!

(Se eu fosse você)

In the examples above, in addition to the alternation of "tu" and "você", a strong residue of diastratic markedness in the use of " $\mathrm{tu}$ " in fiction emerges. In Alemão, Cidade dos Homens, Meu Nome não é Johnny, Central do Brasil and Verônica, its use can still be considered within the "group jargon" of various social groups, from drug traffickers to organ traffickers and groups adjacent to them, such as police officers. We found a very similar situation with regard to the use of the "tu" in Se eu fosse você. In fact, there is a scene in which Claudio, the main character, mimicks the youth language of his daughter's boyfriend, threatening him with the use of slang ("Sacou?") and using "tu" as a strategy of symmetrical interaction, superimposing the diastratic and diaphasic axes: "Eu manjo a tua praia, viu, garoto?"|"você pensa direitinho onde tu quer enfiar esse teu pauzinho, porque senão um dia tu perde ele!". However, although it does not clearly emerge from the examples analyzed (except the last one), it must be said that, in the current BP of Rio de Janeiro, the use of " $\mathrm{tu}$ " in symmetrical and informal communicative situations is gradually being displaced from the diastratic variation axis to the diaphasic variation axis.

With regard to third person subject pronouns, as previously mentioned, we found 826 occurrences and observed a subject fill rate of $60.89 \%$ (63.09\% for third person 
singular and $47.42 \%$ for third person plural), which is in line with the $58 \%$ rate associated with spontaneous speech (DUARTE, 1995, 2004; BARBOSA; DUARTE; KATO, 2005), but far from the $75.80 \%$ found in urban cult speech data (BERLINCK; DUARTE; OLIVEIRA, 2015).

Nonetheless, as can be clearly seen in Graph 5, there were significant oscillations between the results found for the percentage of expressed subject occurrences. For the third person singular, which never fell below 39.53\% (Meu nome não é Johnny), there was in fact a more marked tendency to fill the subject position, with subject pronoun expression rates almost always higher than $50 \%$ (8 out of 10 films), even reaching $70 \%$ in three films: Pequeno Dicionário Amoroso (1996), O Redentor (2004) and Cidade dos Homens (2007). Such frequencies contrast with those pertaining to the third person plural, where the subject position was filled less than $50 \%$ of the time in four films, and reached $70 \%$ in only one film (Se eu fosse você).

Graph 5. Percentage of overt pronominal subject occurrences - data for 3PS and 3PP.

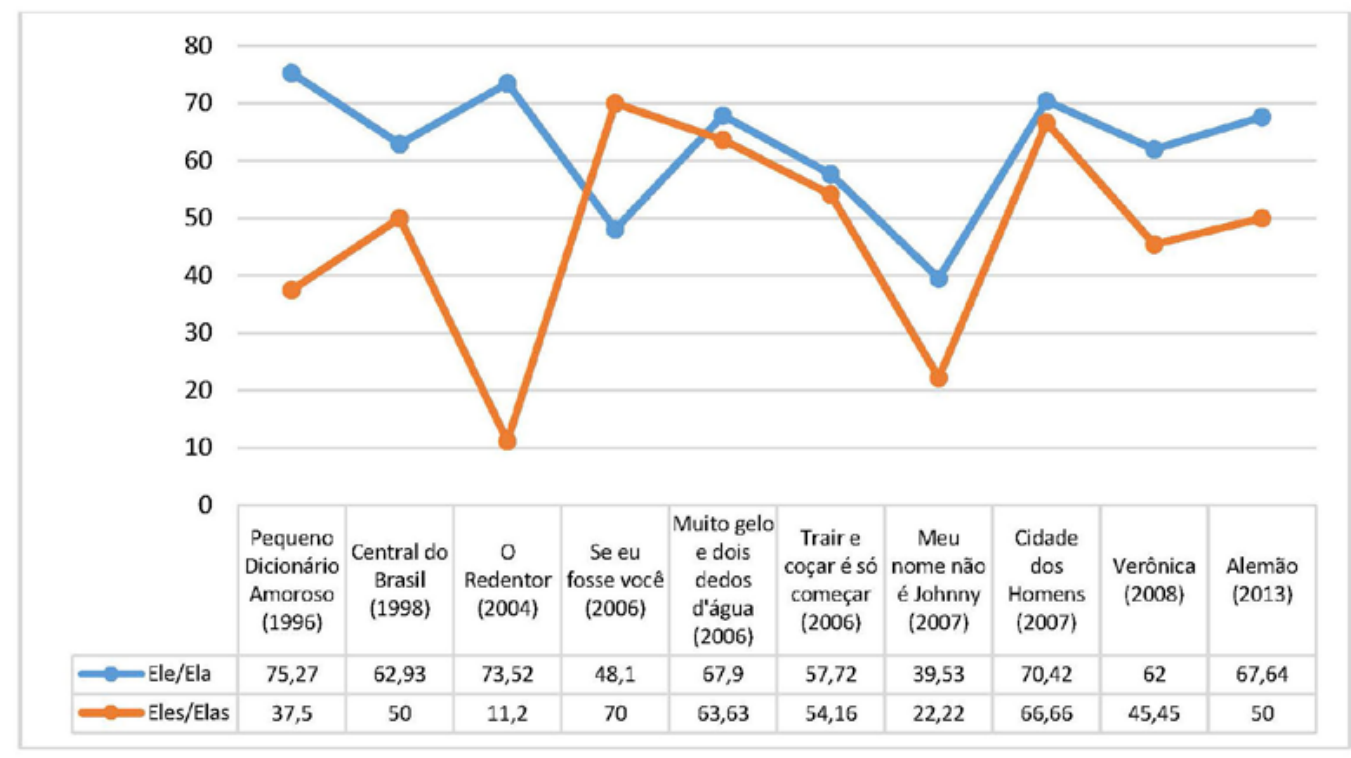


It should, however, be highlighted that the subject position was filled both in cases where the semantic trace of the referent was [+human], [+animate] and [ \pm specific], as well as in cases where it was [-human], [-animate] and [ \pm specific], as the following examples demonstrate:

(16) - Até que o tédio nos atinja, congelando nossos corações e destruindo esse amor que a gente construiu.

- Mas que ele não venha nunca, tá? (Pequeno Dicionário Amoroso)

(17) - Onde é que era essa churrascaria?

- Pô, lá em São Conrado. ø Já fechou já o maior tempão atrás. ø Nem existe mais.

- Como é que ø se chamava?

(Cidade dos homens)

\subsubsection{Linguistic and extralinguistic factors that} favor subject omission

Before detailing the linguistic factors that can be considered contexts of null subject resistance, we should reiterate the specificity of filmic speech which, reproducing different types of communicative and interactive situations, simulates situational speech, with the objective of making the filmic speech more current and recognizable as a credible reproduction of spontaneous speech.

Through this perspective - that of considering filmic speech as a representation of authentic speech, yet at the same time submitted to a whole series of socio-cultural filters -, we can highlight the links that filmic speech builds with shared knowledge schema and with structures linked to the expectations of the target audience.

In addition to the person of the discourse, the linguistic factors examined by our analysis concern time, verb form (simple or compound), type of sentence and the presence of elements before the subject or between subject and verb. We will first analyze the two earliest films: Pequeno Dicionário 
Amoroso and Central do Brasil, to then show a certain continuity in the increasing rate of subject expression.

The null subjects found in these two films correspond to independent sentences, interrogatives, main propositions with the verb in the present or past, often preceded by negation or adverbial locutions, or sentences with a verbal periphrase, as can be seen in the examples:

(18) ø Não preciso nem de dicionário pra vencer você. (Pequeno Dicionário Amoroso)

(19) - ø Posso te fazer uma pergunta?

- $\varnothing$ Vai fazer de qualquer jeito.

(Pequeno Dicionário Amoroso)

(20) - ø Nunca te falei que era farmácia.

- Ontem tu me fez dormir de madrugada.

(Central do Brasil)

(21) - O que é que houve?

- Um ônibus passou em cima de uma mulher.

- ø Morreu?

- Ah, sim. ø Já tá acertando as contas lá em cima. (Central do Brasil)

With regard to second person pronouns, we found in the interrogative sentences one of the main areas of null subject resistance.

(22) ø Já esqueceu que dia é hoje?

(Cidade dos Homens)

(23) ø Tá pensando que ø vai ficar na varanda, meu amor? (O Redentor)

(24) Por que, cara? ø Tem medo de quê?

(Meu nome não é Johnny) 
The aforementioned occurrences confirm what Duarte $(1993,1995)$ had already identified as contexts of overt subject resistance, that is, negative and interrogative phrases. For the latter, in the case of second person pronouns, the occurrences of subject omission are due to the fact that in most cases, in fictional interaction, questions are addressed from speaker to interlocutor in face-to-face communicative situations, with reduced margins of ambiguity.

Regarding third person pronouns, sentences with a marked topic (discursive or syntactic) and those in which the subject referent has another syntactic function or is distant from it favor subject expression.

(25) Pra mim, essa coisa de caça é bem simples. Existe um caçador e uma caça.

No caso do gato, por exemplo, ele é o caçador, e o rato, a sua presa.

(Pequeno Dicionário Amoroso)

(26) - Inclusive, eu não sei se você percebeu, mas eu tava almoçando com o pessoal de... São Paulo, daquela agência...

- Eu sei quem eles são.

(Se eu fosse você)

As for extralinguistic factors, comparing the data regarding the year of production with the characteristics of genre and text type, it emerges that the last three films in the sample, Cidade dos Homens (2007), Verônica (2008) and Alemão (2013), do not have the highest rates of subject expression in the Urban Carioca Sub-Corpus as one might imagine, considering they are more recent and belong to the subgenre "favela movie". On the contrary, the films with the highest overt subject, demonstrating attempts to reproduce more acceptable speech as a reworking of neostandard BP, are the two comedies of 2006 (Se eu fosse você and Muito gelo e dois dedos d'água) and a drama (O Redentor) from 2004 , with $73.31 \%, 73.12 \%$ and $75.14 \%$ subject expression, respectively. 
Therefore, textual genre factors, by type of reproduction of the characters' sociolinguistic traits and year of production, did not show a higher or lower level of linguistic conservatism. In fact, a significant reduction in the so-called socio-cultural filters associated with audiovisual text production can be noted, which is reflected in filmic speech being more credible and closer to neostandard BP. In our case, such proximity arises from the subject position constantly being filled in all the films analyzed.

\section{Conclusion}

From analyzing all the data, it emerges that in filmic speech, the non-standard pronouns "você", "a gente" and "vocês" were registered among the highest rates of subject pronoun expression, with $71.12 \%, 96.46 \%$ and $81 \%$ respectively. This is a consequence of the fact that verbal desinences are still strong factors contributing to null subject expression. This situation also corroborates Duarte's (1993) observation that second person pronoun contexts are the situations that most reveal the current language change, given that the reduction and reorganization of the inflectional paradigm began from there.

As for third person pronouns, we recorded a subject expression rate of $60.89 \%$ on average, but with different values for singular and plural. Indeed, third person singular (710 occurrences) attained a $63.09 \%$ fill rate, while third person plural (116 occurrences) arrived at no more than $47.42 \%$ subject expression. This also highlighted the fact that the third person - by its anaphoric character - is the factor delaying the process (DUARTE, 2012, 26), still allowing a high percentage of referential subject omission.

With regard to sentence ty pes, interrogative and negative sentences appear to favor the non-expression of the subject, with the latter especially facilitating the omission of the pronouns "eu", "nós", "você" and "vocês". Lastly, with regard to extralinguistic factors, we did not find any significant differences in overt subject pronoun rates owing to film genre or year of production.

In summary, the results obtained from data that considered only referential subject pronouns (overt or null) 
of finite time sentences confirm that neostandard BP can be considered a partial pro-drop (variety of) language since, as we stated and also observed in filmic speech, there are still several contexts of resistance where the referential subject pronoun can be omitted.

\section{REFERENCES}

ALARCOS LLORACH, E. Gramática de la Lengua Española. Madrid: Espasa Calpe, Real Academia Española, 1999.

BARBOSA, P.; DUARTE, M.E.L.; KATO, M.A. Null subjects in European and Brazilian Portuguese. Journal of Portuguese Linguistics, 4, p. 11-52, 2005.

BERLINCK, R. de A.; DUARTE, M.E.L.; OLIVEIRA, M. de. Predicação. In: KATO, M.A.; NASCIMENTO, M. do (orgs.). A Construção da Sentença. Gramática do Português Culto Falado no Brasil. São Paulo: Editora Contexto, p. 81-149, 2015, V. II.

CHOMSKY, N. Lectures on Government and Binding. Dordrecht: Foris, 1981.

CYRINO, S.; DUARTE, M.E.L.; KATO, M.A. Visible subjects and invisible clitics in Brazilian Portuguese. In: KATO, M.A.; NEGRÃO, E.V. (orgs.). Brazilian Portuguese and the null subject parameter. Frankfurt am Main/Madrid: Vervuert/ Iberoamericana, 2000, p. 55-74.

DE ROSA, G.L. Mondi Doppiati. Tradurre l'audiovisivo dal portoghese tra variazione linguistica e problematiche traduttive. Milan: Franco Angeli, 2012.

. Il soggetto nel parlato filmico brasiliano contemporaneo.

Rivista di Studi Portoghesi e Brasiliani, XVII - 2015, Pisa-Roma, p. 67-81, 2017.

. et al. Corpus I-Fala, Luso-Brazilian Film Dialogues as a resource for L1 \& L2 Learning and Linguistic Research, 2017. 
DUARTE, M.E.L. Do pronome nulo ao pronome pleno: a trajetória do sujeito no português do Brasil. In: ROBERTS, I.; KATO, M.A. (orgs.). Português brasileiro: Uma viagem diacrônica. Homenagem a Fernando Tarallo. Campinas: Editora da Unicamp, 1993.

. A perda do princípio Evite Pronome no português brasileiro. 1995. 151 f. Tese de Doutorado (Doutorado em Ciência) Curso de Linguística do Instituto de Estudos da Linguagem, Universidade Estadual de Campinas, Campinas, 1995.

O sujeito nulo no português do Brasil: de regra obrigatória a regra variável. In: GROSSE, S.; ZIMMERMANN, K. (orgs.). Substandard e mudança no português do Brasil. Frankfurt: Teo Ferrer de Mesquita (TFM), 1998, p. 189-202.

DUARTE, M.E.L. The loss of the 'avoid pronoun' principle in Brazilian Portuguese. In KATO, M.A.; NEGRÃO, E.V. (orgs.). Brazilian Portuguese and the null subject parameter. Frankfurt am Main: Vervuert/Iberoamericana, 2000, p. 17-36.

. On the 'embedding' of a syntactic change. In Language Variation in Europe. Papers from ICLa VE2 - Second International Conference on Language Variation in English. Uppsala: Universitetstryckeriet, p. 145-155, 2004.

Sujeito Nulo/Pleno e marcas de concordância. In: VOTRE, S; RONCARATI C. (orgs.). Anthony Julius Naro e a Linguística no Brasil. Uma homenagem acadêmica, Rio de Janeiro: 7Letras, 2008, p. 265-277.

. (org.). O sujeito em peças de teatro (1833-1922). Estudos diacrônicos, São Paulo: Parábola, 2012.

KAISER, G.A. Sobre a (alegada) perda do sujeito nulo no português brasileiro. In: LOBO, T. et al. (orgs.). Para a história do português brasileiro. Vol. 6: Novos dados, novas análises. Tomo 1, Salvador: Editora da Universidade Federal da Bahia, 2006, p. 11-42.

KATO, M.A. The Partial Pro-Drop Nature and the Restricted Vs Order in Brazilian Portuguese. In: ; NEGRÃO, E.V. (orgs.). 
Brazilian Portuguese and the null subject parameter. Frankfurt am Main: Vervuert/IberoAmericana, 2000, p. 223-258.

;DUARTE, M.E.L. A Variação entre construções finitas pessoais e impessoais no português brasileiro. Sociodialeto, Campo Grande, 4, 12, 2014, p. 153-177.

LIRA, S. de A. O sujeito pronominal no português falado e escrito. Ilha do Desterro. Florianópolis: UFSC, n. 20, p. 31-43, 1988. The Subject in Brazilian Portuguese. New York: P. Lang, 1996.

LOBO, M. Sujeito Nulo: Sintaxe e Interpretação. In: RAPOSO, E.P. et al. (eds.), Gramática do Português. Lisboa: Fundação Calouste Gulbenkian, 2013, p. 2309-2335, V. II.

LUCCHESI, D. A realização do sujeito pronominal. In: LUCCHESI, D.; BAXTER; A.; RIBEIRO, I. (orgs.), O Português Afro-Brasileiro. Salvador: EDUFBA, 2009, p. 167-183.

PAREDES da SILVA, V.L. Cartas Cariocas: a variação do sujeito na escrita informal. 1988. $320 \mathrm{f}$. Tese de Doutorado (Doutorado em Linguística) - Faculdade de Letras, Universidade Federal do Rio de Janeiro, Rio de Janeiro, 1988.

Cartas Cariocas: a variação do sujeito na escrita informal. Boletim da Abralin, vol. 8, n.11, p. 3-96, 1991.

Motivações funcionais no uso do sujeito pronominal: uma análise em tempo real. In: DUARTE, M.E.L.; PAIVA, M. da C. (orgs.). Mudança lingüística em tempo real. Rio de Janeiro: Contra Capa Livraria, 2003, p. 97-114.

RIZZI, L. Issues in Italian Syntax. Dordrechet: Foris, 1982.

TARALLO, F. Diagnosticando uma gramática brasileira: o português d'aquém e d'além-mar ao final do século XIX. In ROBERTS, I.; KATO, M.A. (orgs.), Português Brasileiro. Uma viagem diacrônica. Homenagem a Fernando Tarallo. Campinas: Editora Unicamp, 1993, p. 69-106. 


\section{Resumo}

\section{Sujeitos nulos na fala fílmica brasileira contemporânea}

O presente contributo, baseado numa amostra de fala fílmica brasileira contemporânea - Urban Carioca Sub-Corpus do I-Fala: Corpus of Luso-Brazilian Film Dialogues as a resource for L1 \& L2 Learning and Linguistic Research (DE ROSA et al., 2017) -, propõe-se observar o processo de transformação que está atingindo o português brasileiro $(P B)$ que está perdendo, à luz de toda uma série de mudanças linguísticas, as caraterísticas de uma língua de sujeito nulo. Nesse contributo, revisitamos De Rosa (2017), incluindo os sujeitos de terceira pessoa, sempre com o objetivo de registrar, em termos quantitativos e qualitativos, a presença do sujeito pleno nos diálogos filmicos analisados $e$ de confrontar os resultados com os dados da fala espontânea.

Palavras-chave: Português brasileiro; línguas de sujeito nulo; sujeitos referenciais; fala fímica; Português europeu. 